\title{
Clinical Features and Neurodevelopmental Outcomes of Infants with Congenital Cytomegalovirus Infection: Single NICU Experience
}

Ji Hee Kim, M.D., Sung Hun Chung, M.D., Yong Sung Choi, M.D., Byong Sop Lee, M.D., Ki-Soo Kim, M.D., and Ellen Ai-Rhan Kim, M.D.

Division of Neonatology, Department of Pediatrics, Asan Medical Center, University of Ulsan College of Medicine, Seoul, Korea

\section{ABSTRACT}

Purpose: To assess the clinical features, hearing loss and neurodevelopmental outcomes of infants with congenital cytomegalovirus (CMV) infection and to discover significant brain magnetic resonance imaging (MRI) findings that predict poor neurodevelopmental outcomes.

Methods: The medical records of 31 infants who were diagnosed with congenital CMV infection at the Neonatal Intensive Care Unit of Asan Medical Center between 2002 and 2012 after CMV was isolated from their urine within the second week of their life were retrospectively reviewed. The long-term neurodevelopmental outcomes of the infants were monitored using the Bayley Scale of Infant Development II, the Korean Infants' Development Screening Test and the Wechsler Scale of Intelligence, as appropriate.

Results: The infants' mean gestational age was $36.3 \pm 3.2$ weeks and their mean birth weight was 2,395 $\pm 715 \mathrm{~g}$. Microcephaly were detected in three of them (9.7\%), and petechiae and hepatosplenomegaly were detected in one (3.2\%). Ten infants $(32.2 \%)$ and nine infants $(29.0 \%)$ showed preterm and intrauterine growth retardation, respectively. Of the 27 infants with whom long-term follow-up was possible, six (22.2\%) showed developmental disabilities. The brain MRI findings, which included ventriculomegaly, periventricular calcification, polymicrogyria, microcephaly and cerebellar hypoplasia, were correlated with the poor neurodevelopmental outcomes, but no correlation was found between the presence of periventricular cysts and that of white matter disease. Of the infants who survived, six (20.0\%) had sensorineural hearing loss at the median age of 30.6 months.

Conclusion: Congenital cytomegalovirus infection is one of the most frequent causes of intrauterine viral fetal infection and need to be distinguished if congenital infection is suspected. On the follow up observation, the hearing loss was observed in $20 \%$ of the patients. A long term neurological observation is required for the patients who had unusual impression on MRI.

Key Words: Congenital cytomegalovirus infection, Hearing loss, Brain MRI, Long term neuro-developmental outcomes, Neonatal intensive care unit
Received: 18 March 2013

Revised: 12 May 2013

Accepted: 24 May 2013

Correspondence to:

Ellen Ai-Rhan Kim, M.D.

Division of Neonatology, Asan

Medical Center Children's

Hospital, Ulsan University College of Medicine, 88 Olymphic-ro 43gil, Songpa-gu, Seoul 138-736, Korea

Tel: +82-2-3010-3382,

Fax: +82-2-3010-6978,

E-mail: arkim@amc.seoul.kr

*The abstract was presented as a poster at 19th Annual Autumn Meeting of the Neonatology.

Copyright(c)

By Korean Society of Neonatology. All right reserved. 
서론

선천성 거대세포바이러스(cytomegalovirus, CMV)는 자궁 내 태 아감염의 가장 흔한 바이러스성 원인으로 감염된 태아의 일부에 서 선천성 기형, 신경 발달 장애와 청력상실 등을 일으킨다 ${ }^{1-3)}$.

$\mathrm{CMV}$ 는 헤르페스 바이러스의 일종으로 접촉을 통해 감염된다 ${ }^{1,2)}$. 주로 소변, 질 분비물, 타액, 정액, 모유, 혈액, 이식된 장기를 통해 전염될 수 있고 태반을 경유하여 태아에게 감염되어 선천 성 CMV감염을 일으킬 수 있달. 이 바이러스는 일생을 통해 대부 분의 사람들이 감염되는 독특한 바이러스로 항체 보유율은 연령 에 따라 증가한다 ${ }^{4}$. 선진국의 경우 산모의 $60 \%$, 개발도상국의 경 우 산모의 $90 \%$ 에 이르는 높은 항체 보유율을 나타내며 대부분 무 증상이나 잠재성 감염이나 재감염을 일으킬 수 있다 ${ }^{5,6}$. 태아로의 감염은 산모로부터 일차적 또는 재활성된 감염을 통해 일어나며 초 회 감염된 산모의 $32-40 \%$, 재활성화 되었거나 재발된 산모의 $0.2-1.8 \%$ 에서 발생하게 된다.,8)

감염된 환자 중 태어나서 증상이 있는 경우는 약 $10 \%$ 이고 나머 지 $90 \%$ 는 무증상으로 출생한다 ${ }^{3,7)}$. 출생 시 $\mathrm{CMV}$ 감염으로 인한 증 상이 있는 신생아의 약 60-90\%에서 그리고 증상이 없는 신생아 의 약 10-15\% 에서 신경 발달 장애나 시력 소실과 같은 신경학적 후유증이 발생한달.

선천성 CMV 감염 빈도는 약 $0.15-2.2 \%$ 로 지역별, 인종별로 다 양하며 우리나라에서도 비슷한 빈도로 보고 되고 있다 ${ }^{10}$. 우리나 라에서 시행된 연구 중 선천성 $\mathrm{CMV}$ 감염의 진단에 대한 연구 ${ }^{11-13)}$, 2001 년 청력 장애가 동반된 유증상 선천성 CMV 감염 신생아 1례 ${ }^{14)}, 2002$ 년 이들의 임상 증상 고찰에 대한 연구 ${ }^{15)}, 2012$ 년 감각신경 성 난청을 동반한 선천성 CMV 감염 신생아의 청력 회복 1 례 ${ }^{16)}$, 신 생아 및 영아 뇌초음파상 시상과 기저핵의 선상 고반향성 혈관을 보였던 환아 53 례 중 5 례에서 선천성 혹은 주산기성 $\mathrm{CMV}$ 감염 환 자였다는 연구 ${ }^{17}$ 가 있었으나 선천성 CMV 감염 환자의 방사선학 적 소견, 장기적 후유증에 대한 연구는 부족한 실정이다. 이에 본 연구는 단일 신생아중환자실에서 경험한 선천성 $\mathrm{CMV}$ 감염으로 진단된 환자의 초기 임상 양상 및 청력 손상과 발달 장애를 포함한 예후를 알아보고, 신생아시기에 얻은 뇌 자기공명 소견과 장기적 신경발달학적 예후와의 관계를 분석하고자 하였다.

\section{대상 및 방법}

2002년부터 2012년까지 서울아산병원 신생아중환자실로 입원 한 신생아 중 자궁 내 성장 지연, 산전 뇌 초음파상 이상 소견, 출 생 후 미숙아, 소두증, 간비종대, 점상 출혈등의 임상 소견과 혈액 검사상 혈소판 감소증, 백혈구 감소증, 직접 빌리루빈 수치 증가
등의 소견으로 선천성 CMV 감염이 의심되어 생후 2 주 이내 시행 한 소변 배양 검사 상 CMV가 분리된 환자를 대상으로 이들의 출 생 시 재태연령, 출생체중, 두위, 신장 등의 신체 계측 및 주산기 임상 소견과 혈액 검사, 뇌척수액 검사, 방사선학적 검사 소견 등 에 대한 임상자료를 후향적으로 조사하였다.

자궁내 성장 지연은 태아가 해당 임신 주수의 평균 태아의 체중 보다 10 백분위수 미만인 경우, 소두증은 두위가 같은 나이에 비해 2 표준편차 미만인 경우, 직접 고빌리루빈 혈증은 직접 빌리루빈 $>3 \mathrm{mg} / \mathrm{dL}$, 혈소판 감소증은 혈소판 수 $\left\langle 100,000 / \mathrm{mm}^{3}\right.$, 백혈구 감 소증은 백혈구 수 $\left\langle 4,000 / \mathrm{mm}^{3}\right.$, 뇌척수액 백혈구 증가증은 뇌척수 액 백혈구 수 $>22$ cells $/ \mathrm{mm}^{3}, 2,500 \mathrm{~g}$ 미만인 경우 저체중 출생아, $1,500 \mathrm{~g}$ 미만인 신생아를 극소 저체중 출생아, 성장 부진은 키와 몸무게가 지속적으로 같은 나이의 소아에 비해 3 백분위수 이하 로 낮게 유지될 때로 정의하였다.

대상군의 모든 신생아는 신생아중환자실 입원 기간 동안 청각 유발 반응 검사, 안과적 검사, 뇌 초음파 검사를 시행하였으며 뇌 초음파에 이상이 있거나 신경학적 증상이 있는 경우 뇌 자기공명 영상(MRI)을 시행하였다. 추적관찰 중 본 연구시점까지 발달검 사가 시행되지 않았던 경우, 교정나이 혹은 생일나이18-42개월 때 베일리 영유아 발달 검사(Bayley scales of infant development II)를 시행하였고 시행할 수 없는 경우 한국형 영유아 발달 검사 를 시행하였다. 6 세 이상의 소아에서는 웩슬러 지능 검사를 시행 하여 발달 장애 유무를 조사하여 이들의 신경학적 발달 상태와 신 생아시기 때 얻은 뇌 MRI의 이상 소견과의 관계를 분석하였다. Ganciclovir 치료 적응증은 신생아 중환자실 입원 기간 동안 신경 학적 증상이 있었던 경우 또는 주치의의 판단 하에 치료 여부를 결 정하였다.

통계적 방법은 SPSS version 13.0을 사용하였으며, 방사선학 적 특성과 예후의 비교 검정을 위해 t-test와 chi-square, Fisher's exact test검사를 이용하여 $P$ 값이 0.05 미만인 경우를 통계학적으 로 유의성이 있는 것으로 판단하였다.

\section{결과}

2002년부터 2012년까지 총 연구 대상은 31명으로 남녀 비 는 $1.1: 1$ 이었고 평균 재태 연령은 $36.3 \pm 3.2$ 주, 평균 출생체중은 $2,395 \pm 715 \mathrm{~g}, 37$ 주 미만 미숙아는 10명(32.2\%)이었다. 자궁 내 발 육 지연은 9 명 $(29 \%)$, 저체중 출생아는 13 명 $(41.9 \%)$, 극소 저체중 출생아는 2 명 $(6.5 \%)$ 이었다(Table 1).

임상 소견으로는 소두증 3 명 $(9.7 \%)$ 이었고 점상 출혈, 간비종 대, CMV로 인한 폐렴이 각각 1 명 (3.2\%)이었다(Table 1). 혈액 검 사상 혈소판 감소증 11 명(35.5\%), 백혈구 감소증 4 명(12.9\%), 직접 
고빌리루빈 혈증은 3 명 $(9.7 \%)$ 이었다. 혈청 CMV IgM 검사는 검 사를 시행한 26 명의 환아 중 15 명(57.7\%)에서 양성 소견을 보였으 며 뇌척수액 $\mathrm{CMV}$ 중합효소 연쇄반응 검사는 24 명에서 시행하였

Table 1. Clinical Characteristics of Infants with Congenital Cytomegalovirus Infection

\begin{tabular}{lc}
\hline Characteristics & Values, $\mathrm{n}(\%)$ \\
\hline Gestational age (weeks) & $36.3 \pm 3.2^{*}$ \\
Birth weight (g) & $2395 \pm 715^{*}$ \\
Gender (male) & $16(51.6 \%)$ \\
Preterm & $10(32.2 \%)$ \\
Low birth weight & $13(41.9 \%)$ \\
Intrauterine growth retardation & $9(29.0 \%)$ \\
Nonimmune hydrops fetalis & $1(3.2 \%)$ \\
Hepatosplenomegaly & $1(3.2 \%)$ \\
Petechiae & $1(3.2 \%)$ \\
Pneumonitis & $1(3.2 \%)$ \\
Seizure & $7(23.3 \%)$ \\
Microcephaly & $3(9.7 \%)$ \\
Chorioretinitis & $0(0 \%)$ \\
Total patients & 31
\end{tabular}

*mean \pm standard deviation.

Table 2. Laboratory Findings of Infants with Congenital Cytomegalovirus Infection

\begin{tabular}{lc}
\hline & $\mathrm{n}(\%)$ \\
\hline Leukopenia & $4(12.9 \%)$ \\
Thrombocytopenia & $11(35.5 \%)$ \\
Direct hyperbilirubinemia & $3(9.7 \%)$ \\
Hepatitis & $0(0 \%)$ \\
Serum CMV IgM(+) & $15 / 26(57.7 \%)$ \\
CSF CMV PCR(+) & $0 / 24(0.0 \%)$ \\
CSF pleocytosis & $0 / 24(0.0 \%)$ \\
Total patients & 31 \\
\hline
\end{tabular}

는데 모두 음성이었다(Table 2). 뇌초음파상 이상 소견을 보인 15 명의 환자를 대상으로 뇌 자기 공명 영상 검사(MRI)를 시행하였 고, 뇌MRI검사 결과 뇌실확장증 12 명(38.7\%), 뇌실 주위 낭종 10 명(32.2\%), 뇌실 주위 석회화 6명(19.4\%), 뇌백질 병변은 각각 3명 (10\%) 이었다 (Table 3).

신생아중환자실에서 퇴원 시 시행한 청각 유발 전위 검사 결과 사망한 1 명의 환자를 제외하고 정상인 경우는 22 명(73.3\%)였고 비 정상인 경우는 8 명 $(26.7 \%)$ 이었다. 정상인 경우 평균 28.6 개월 외 래 추적 관찰 상 청력 소실이 의심되는 환자는 없었고 비정상인 환 자를 대상으로 평균 30.6 개월 추적 관찰 한 결과 이 중 2 명(25.0\%) 은 재검에서 정상 소견을 보였고, 나머지 6명(75.0\%)은 감각 신경 성 청력 소실을 보였으며 4 명은 편측성, 2 명은 양측성 청력 소실 을 보였다. 총 31 명의 대상 환자 중 출생 시 증상이 있었던 환자는 29 명(93.5\%), 출생 시 증상이 없었던 환자는 2 명(6.5\%)으로 산전 뇌실확장증 소견만 보였다. 감각 신경성 청력 소실을 보인 6 명 모 두 출생 시 증상이 있었던 환자였다.

한국형 영유아 발달 검사는 평균 16.9 개월에 8 명에게 시행하였 으며 베일리 영유아 발달 검사는 평균 30.6 개월에 16 명을 대상으 로 시행하였다. 베일리 영유아 발달 검사 결과 인지발달지수, 동

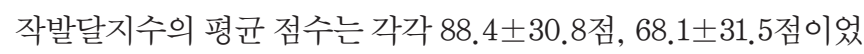
다. 웩슬러 지능 검사를 시행한 3 명은 평균 84 개월에 검사를 시 행했으며 3명 모두 정상 범위 안에 있었다. 즉, 현재12개월 미만 인 3 명과 사망한 1 명을 제외한 총 27 명의 추적관찰 대상자 중 6 명 (22.2\%)은 발달 장애 소견을 보였고 21 명(77.8\%)은 정상 발달을 하 고 있었다.

발달 검사를 시행하고 외래 추적 관찰 중인 27 명 중6주 동안 Ganciclovir (Cymevene vial) $6 \mathrm{mg} / \mathrm{kg}$, 하루 2회로 치료를 한 6 명 의 환자 중 3 명(50.0\%)은 발달 장애를 보였고 감각 신경성 청력 소 실을 보인 환자는 1 명(16.7\%)이었다.

뇌 MRI에서의 비정상적인 소견을 보이는 군과 정상 군을 나누 어 발달 장애 여부를 조사한 결과 뇌실확장증, 뇌실 주위 석회화,

Table 3. Correlation between Abnormal MRI Findings and Neurodevelopmental Disability in Infants at 18 to 116 Months Corrected Age with Congenital CMV Infection

\begin{tabular}{lccc}
\hline Cerebral lesion & $\begin{array}{c}\text { Numbers of Infants with } \\
\text { Neurodevelopmental disability (n=6) }\end{array}$ & $\begin{array}{c}\text { Numbers of Infants with } \\
\text { Normal outcome (n=21) }\end{array}$ \\
\hline Ventriculomegaly & 6 & 6 & 0.003 \\
Intracranial calcification & 4 & 2 & 0.011 \\
Polymicrogyria & 5 & 3 & 0.001 \\
Periventricular cysts & 1 & 0 & 0.363 \\
Cerebellar hypoplasia & 3 & 1 & 0.007 \\
White matter disease & 3 & 1 & 0.115 \\
Porencephalic cysts & 0 & 1 & 1.00 \\
Lentriculostriate vasculopathy & 0 & 1.00 \\
\hline
\end{tabular}




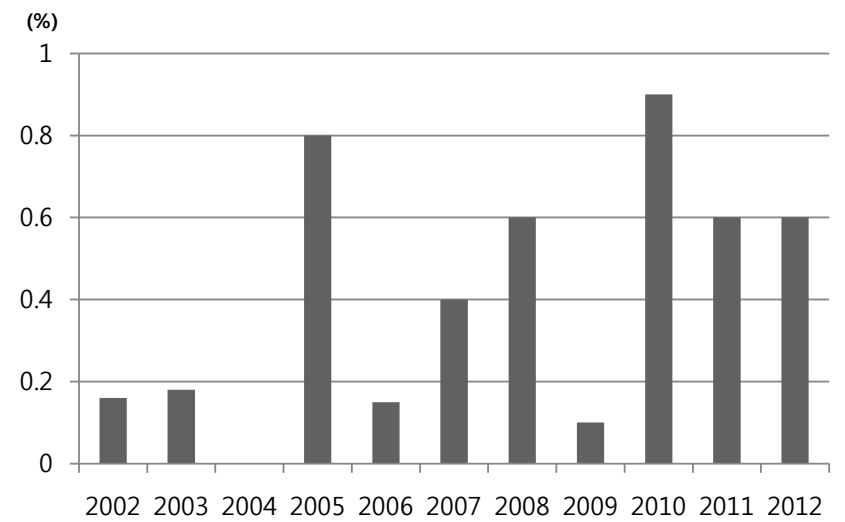

Fig.1. Prevalence of infants diagnosed with congenital CMV infection per year.

다소뇌회증, 소뇌 형성 부전 소견와 발달 장애간에는 통계학적으 로 유의한 상관성을 보였고 $(P<0.05)$, 뇌실 주위 낭종, 뇌백질 병변 과는 유의한 상관성을 보이지 않았다(Table 3). 산전 태아 초음파 상 단순 뇌실확장증이 진단된 경우는 전체 31 명 중 14 명(45.2\%)이 었다.

지난 2002년부터 2012년까지 신생아중환자실에 입원된 환아 중 $\mathrm{CMV}$ 감염이 의심되어 진단된 환자의 연도별 발병률은 연도별 로 $0.4 \%$ 정도였고 (Fig. 1), 현재까지 평균 36.4개월 동안 추적 관찰 중이다. 외래 추적 관찰 시 성장 부진을 보인 경우는 3 명(11.5\%)이 었다. 신생아중환자실 입원 기간 및 외래 추적 관찰 기간 동안 경 련이 관찰된 환자는 7명(23.3\%)이었다.

사망한 환자는 1 명으로 출생 후 신생아 중환자실 입원 기간 중 사망하였으며 저산소성 허혈성 뇌증으로 진단 받아 사망의 원인 은 선천성 $\mathrm{CMV}$ 감염과는 무관하였다.

\section{고찰}

선천성 $\mathrm{CMV}$ 감염은 미국과 북서유럽의 전체 신생아의 약 $1 \%$ 에서 선천성 감염을 일으키는 원인이며 ${ }^{3,7}$ 위험 요인으로는 백인이 아닌 인종, 낮은사회 경제 계층, 미숙아, 신생아 중환자실에 입원하게 되 는 경우 등으로 알려져 있다 ${ }^{18)}$. 증상이 있는 선천성 감염 환자의 경 우 임상 양상이 매우 다양하게 나타나는데 출생 후 점상 출혈, 간비 종대, 황달이 가장 흔한 임상 증상이며 그 외 자궁 내 성장 지연, 뇌 실확장증, 소뇌증, 뇌실 주위 석회화 등의 증상을 보일 수 있으며 청 력장애, 맥락망막염, 지능저하, 발달 장애, 경련, 시력 소실과 같은 후유증이 나타날수 있닥.

선천성 $\mathrm{CMV}$ 의 가장 흔한 임상 증상은 감각 신경성 난청이다. 출생 시 증상이 있는 환자의 약 22-65\%, 증상이 없었던 환자의 약
6-23\%가 청력 소실을 보이게 된다. 출생 시 증상이 있었던 그룹에 서 더 심한 청력 소실의 형태를 보이며 점점 진행하거나 나중에 발 견될 수도 있기 때문에 6 세까지 규칙적인 추적 검사가 필요하다 ${ }^{9,19,20)}$. Noyola 등 ${ }^{21)}$ 은 출생 시 증상이 있었던 41 명의 선천성 $\mathrm{CMV}$ 환자 를 대상으로 평균 5.7년 추적 관찰한 결과 17명(41.5\%)에서 신생아 시기에 청력 소실을 보였으며 11 명(26.8\%)은 추적 관찰 기간 동안 청 력 소실을 보였다고 하였다. 본 연구에서는 출생 시 증상이 있었던 29 명의 환자 중 6 명 $(20.7 \%)$ 에서 청력 소실을 보이고 있었는데 이는 신생아 시기에 청각 유발 반응 검사가 정상인 경우 청력 검사를 더 이상 시행하지 않았으며 평균 28.6 개월로 외래 추적 기간이 짧았기 때문인 것으로 생각된다. 양측성 감각 신경성 청력 소실을 보인 2 명 의 환자 중 1 명은 인공 와우 이식수술을 시행 받았고 2 명 모두 정상 발달을 하고 있었다. 최근 연구에서는 생후 6 개월 이전에 청력 손상 을 진단할 경우 빠른 치료가 가능하고 언어나 말하기뿐만 아니라 행 동이상도 빨리 발견하여 치료할수 있다고 보고하였다 ${ }^{19}$.

태아의 뇌는 선천성 $\mathrm{CMV}$ 에 감염이 되기 쉬운 기관으로 뇌 손상 의 기전은 정확하게 알려지지 않았다. CMV가 뇌 세포자멸사 과정 에서 기형 유발물질로 작용한다는 설, 면역 반응 이상이나 염증 반 응을 통해 중추신경계 손상을 가져온다는 설, 혈관 내에 병원체로 작용한다는 설 등이 제시되고 있다. CMV 감염으로 나타날 수 있는 뇌 주위 석회화, 뇌실확장증, 뇌백질 병변, 신경세포이주장애, 소뇌 증, 뇌실 주위 낭종, 렌즈핵 선조체성 혈관병증, 뇌실 중격 형성 결 손이나 유착, 해마 형성 이상 등을 16,22$)$ 찾아내기 위하여 시행할 수 있는 뇌 영상 검사로는 뇌 초음파, 뇌 컴퓨터 단층 촬영(CT), 뇌 MRI 를 할 수 있다. 본 연구에서는 우선 환자의 상태가 나쁘더라도 시행 할 수 있고 비용이 적게 들고 필요하면 반복적으로 시행할 수 있는 뇌 초음파 검사를 선별검사로 시행하였고 이상 소견이 발견되면 대 뇌 겉질 부위나 뇌의 뒤쪽 병변을 포함한 뇌 병변 소견의 확인을 위 하여 뇌 MRI를 하였는데 뇌 초음파 소견으로 보이지 않던 다소뇌회 증, 뇌회결손과 같은 신경세포이주 장애나 뇌백질 병변등이 발견되 었다. 본 연구에서는 뇌 MRI 검사상 뇌실확장증, 뇌실 주위 석회화, 다소뇌회증의 경우 Manara 등 ${ }^{23)}$ 의 연구와 흡사하게 발달 장애와 통계학적으로 연관이 있었고 뇌실 주위 낭종, 뇌백질 병변과는 통 계학적 연관이 없었다. 이와 같은 결과는 입원 기간 동안 뇌초음파 가 정상이면서 신경학적 증상이 관찰되지 않은 환자의 경우 뇌 MRI 검사를 시행하지 않았고 대상 환자 수가 적다는 점에서 확실한 결론 을 내기에는 제한점이 있다.

Noyola 등 21) 은 출생 시 증상이 있는 환자에서 소뇌증이 있거나 뇌 컴퓨터 단층 촬영상 뇌실확장증, 뇌실 주위 석회화 등의 이상이 있 는 경우 예후가 나쁘다고 하였고 그 밖의 여러 연구들에서도 소뇌증 이 신경학적 손상을 가장 잘 예측할 수 있는 지표가 된다고 하였다 ${ }^{24)}$. 본 연구에서도 두위가 같은 연령 평균값에 비해 2 표준편차 미만 이면서 뇌 MRI에서 이상 소견을 보인 3 명의 환자 모두 발달 지연 소 
견을 보였다. 반면에 두위가 정상 범위이고 뇌 초음파 검사상 정상 인 환자는 모두 정상 발달하고 있다.

$\mathrm{CMV}$ 를 진단하는 방법으로는 중합 효소 연쇄 반응법, 조직 병리 검사법, early $\mathrm{CMV}$ 항원을 이용한 직접 면역 형광염색법, $\mathrm{CMV}$ 에서 생성되는 조기 단백질에 대한 단세포군 항체를 이용하는 방법이 있 으나 ${ }^{25,26)}$ 선천성 $\mathrm{CMV}$ 감염의 확진 방법은 생후 2 주 내에 소변이나 타액을 통해서 바이러스를 분리하는 것이다 ${ }^{27,28)}$. 신생아 혈액이나 제대혈의 특이 $\mathrm{IgM}$ 을 통해서도 알 수 있는데 이는 실제 감염된 환 아의 70\%에서 발견된다고 알려졌는데 ${ }^{15,28-30}$ 본 대상자의 경우 CMV $\mathrm{IgM}$ 소견은 $57.7 \%$ 에서 양성 소견을 보였다.

선천성 $\mathrm{CMV}$ 환자의 경우 소뇌증, 경련, 비정상적인 뇌척수액 검 사소견, 비정상적인 뇌 영상소견, 청력 손상, 맥락망막염 등 중추 신경계 증상이 있는 경우 생후 한달 이내에 정맥을 통해 ganciclovir 로 6 주 동안 치료를 하는 것이 발달지연과 청력 손상을 예방하는데 효과적이라고 알려져 있다 ${ }^{31)}$. 하지만 적응증, 방법, 용량, 치료 기 간에 대해서는 현재까지 논란의 여지가 있는 상태이다 ${ }^{32)}$. 최근에 는 gancilovir의 전구약으로 경구 제제인 valganciclovir만으로 치료 한 연구가 진행 중이고 CASG (The National Institute of Allergy and Infectious Diseases Collaborative Antiviral Study Group)에서 6주간 ganciclovir로 치료한 군과 6 개월간 valganciclovir로 치료한 군 간의 연구가 진행 중이다.).

본 연구에서는 9 명의 환자가 신생아 시기에 ganciclovir로 6 주 동 안치료를 받았으며 이 중 1 명의 환자는 치료 중 호중구 감소증을 보 였다. Ganciclovir로 치료를 받은 환자 중 청력 소실을 보인 환자는 1 명이었고 신생아 중환자실에서 퇴원 전 시행한 청력 검사 상 비정상 소견을 보였다. 발달 검사를 시행하지 못한 환자 4 명의 환자를 제외 하고 ganciclovir로 치료를 받았던 환자 중 발달 장애를 보인 경우는 3 명 $50 \%)$ 이었는데 모두 신생아시기에 중추신경계 증상과 2 개 이상 의 비정상적인 뇌 자기공명 소견을 보인 경우였다.

본 연구는 신생아중환자실에서 CMV 감염이 의심되어 진단된 $\mathrm{CMV}$ 감염 대상아로 국한 되어있고 모든 추적 대상아들을 베일리 발달검사로 발달여부를 하지 않아 정확한 결론을 내기에는 제한점 이 있다. 따라서 향후 대규모 연구를 바탕으로 선천성 거대세포 바 이러스 감염아와이들의 장기적 예후에 대한 세밀한 추적 관찰이 이 루어져야겠다.

\section{REFERENCES}

1) Ross SA, Boppana SB. Congenital cytomegalovirus infection: outcome and diagnosis. Seminars in pediatr Infect Dis 2005; 16:44-9.

2) Nelson CT, Demmler GJ. Cytomegalovirus infection in the pregnant mother, fetus, and newborn infant. Clin Perinatol 1997;24:151-60.

3) Nassetta L, Kimberlin D, Whitley R. Treatment of congenital cytomegalovirus infection: implications for future therapeutic strategies. J Antimicrob Chemother 2009;63:862-7.

4) Ross DS, Dollard SC, Victor M, Sumartojo E, Cannon MJ. The epidemiology and prevention of congenital cytomegalovirus infection and disease: activities of the Centers for Disease Control and Prevention Workgroup. J Womens Health (Larchmt) 2006; 15:224-9.

5) Stagno S, Pass RF, Cloud G, Britt WJ, Henderson RE, Walton $\mathrm{PD}$, et al. Primary cytomegalovirus infection in pregnancy. Incidence, transmission to fetus, and clinical outcome. JAMA 1986;256:1904-8.

6) Numazaki Y, Yano N, Morizuka T, Takai S, Ishida N. Primary infection with human cytomegalovirus: virus isolation from healthy infants and pregnant women. Am J Epidemiol 1970; 91:410-7.

7) Demmler GJ. Infectious Diseases Society of America and Centers for Disease Control. Summary of a workshop on surveillance for congenital cytomegalovirus disease. Rev Infect Dis 1991;13:315-29.

8) Kenneson A, Cannon MJ. Review and meta-analysis of the epidemiology of congenital cytomegalovirus (CMV) infection. Rev Med Virol 2007;17:253-76.

9) Yamazaki H, Yamamoto R, Moroto S, Yamazaki T, Fujixara K, Nakai M, et al. Cochlear implantation in children with congenital cytomegalovirus infection accompanied by psychoneurological disorders. Acta Otolaryngol 2012;132: 420-7.

10) Elek SD, Stern H. Development of a vaccine against mental retardation caused by cytomegalovirus infection in utero. Lancet 1974;1:1-5.

11) Kim JH, Seo EA, Lim JH, Park SH, Lee WB, Lee KS, et al. Congenital asymptomatic cytomegalovirus infection; a comparison of specific IgM Antibody test and pp65 antigenemia assay. J Korean Pediatr Soc 1998;41:163-9.

12) Lee YA, Lee K, Jo IS, Chung WG. Daignosis of cytomegalovirus infection in neonatal an infantile periods using polymerase chain reaction. J Korean Pediatr Soc 1996;39:1271-9.

13) Kim DW, Kwack H, Jang SH, Kang IS, Lee HJ, Choi JH, et al. Cytomegalovirus infection in children: the significance of CMV specific IgM antibody test and virus isolation in the urine. J Korean Pediatr Soc 1992;35:890-901.

14) Jang SJ, Cho YJ, Lee SL, Kim JS, Kwon TC. A neonatal case of symptomatic congenital cytomegalovirus infection with hearing defect. J Korean Pediatr Soc 2001;44:205-10.

15) Paik SH, Lee YK, Ko SY, Kim KA, Kim MJ, Han BH, et al. Clinical features of congenital cytomegalovirus infection in neonates. Korean J Perinatol 2002;13:413-9. 
16) Lee DY, Park SH, Cha TK, Yoo JC. A case of hearing impro vement in congenital cytomegalovirus infected infants with sensorineural hearing loss. Korean J Otorhinolaryngol-Head NeckSurg 2012;55:582-5.

17) Oh HN, Kang DC, Park MS, Park KI, Lee C. Linear hyperechoic lesions in the thalami and basal ganglia of neonates and infants: a sonographic findings of vasculopathy and clinical significance. J Korean Soc Neonatol 2002;9:74-81.

18) Malm G, Engman ML. Congenital cytomegalovirus infections. Semin Fetal Neonatal Med 2007;12:154-9.

19) Fowler KB, Boppana SB. Congenital cytomegalovirus (CMV) infection and hearing deficit. J Clin Virol 2006;35:226-31.

20) Williamson WD, Demmler GJ, Percy AK, Catlin FI. Progressive hearing loss in infants with asymptomatic congenital cytomegalovirus infection. Pediatrics 1992;90:862-6.

21) Noyola DE, Demmler GJ, Nelson CT, Griesser C, Williamson WD, Atkins JT, et al. Early predictors of neurodevelopmental outcome in symptomatic congenital cytomegalovirus infection. J Pediatr 2001;138:325-31.

22) Boppana SB, Fowler KB, Vaid Y, Hedlund G, Stagno S, Britt WJ, et al. Neuroradiographic findings in the newborn period and long-term outcome in children with symptomatic congenital cytomegalovirus infection. Pediatrics 1997;99:409-14.

23) Manara R, Balao L, Baracchini C, Drigo P, D’Elia R, Ruga EM. Brain magnetic resonance findings in symptomatic congenital cytomegalovirus infection. Pediatr Radiol 2011;41:962-70.

24) Ancora G, Lanari M, Lazzarotto T, Venturi V, Tridapalli E, Sandri F, et al. Cranial ultrasound scanning and prediction of outcome in newborns with congenital cytomegalovirus infection. J Pediatr 2007;150:157-61.
25) Einsele H, Ehninger G, Steidle M, Vallbracht A, Müller M, $\mathrm{Schmidt} \mathrm{H}$, et al. Polymerase chain reaction to evaluate antiviral therapy for cytomegalovirus disease. Lancet 1991; 338:1170-2.

26) Munro SC, Trincado D, Hall B, Rawlinson WD. Symptomatic infant characteristics of congenital cytomegalovirus disease in Australia. J Paediatr Child Health 2005;41:449-52.

27) Stronati M, Lombardi G. Congenital cytomegalovirus infection: diagnosis and management. Pediatr Med Chir 2005;27:36-9.

28) Lazzarotto T, Guerra B, Lanari M, Gabrielli L, Landini MP. New advances in the diagnosis of congenital cytomegalovirus infection. J Clin Virol 2008;41:192-7.

29) Peckham C, Tookey P, Logan S, Giaquinto C. Screening options for prevention of congenital cytomegalovirus infection. J Med Screen 2001;8:119-24.

30) Revello MG, Zavattoni M, Baldanti F, Sarasini A, Paolucci S, Gerna G. Diagnostic and prognostic value of human cytomegalovirus load and IgM antibody in blood of congenitally infected newborns. J Clin Virol 1999;14:57-66.

31) Kimberlin DW, Lin CY, Sánchez PJ, Demmler GJ, Dankner W, Shelton M, et al. Effect of ganciclovir therapy on hearing in symptomatic congenital cytomegalovirus disease involving the central nervous system: a randomized, controlled trial. J Pediatr 2003;143:16-25.

32) Oliver SE, Cloud GA, Sánchez PJ, Demmler GJ, Dankner W, Shelton M, et al. Neurodevelopmental outcomes following ganciclovir therapy in symptomatic congenital cytomegalovirus infections involving the central nervous system. J Clin Virol 2009;46 Suppl 4:S22-6. 


\section{단일 기관에서 경험한 선천성 거대세포바이러스 감염 환자의 임상 양상 및 신경발달 학적추적관찰}

울산대학교 의과대학, 서울아산병원 소아청소년병원, 신생아과

김지희 · 정성훈·최용성 · 이병섭·김기수 · 김애란

목적: 단일 기관의 신생아중환자실에서 경험한 선천성 거대세포바이러스 감염으로 진단된 환자의 임상 양상과 청력 손상 및 발달 장애 여부를 알아보았다.

방법: 2002년부터 2012년까지 신생아 중환자실로 입원한 신생아 중 선천성 거대세포바이러스 감염이 의심되어 생후 2 주 이내 시행한 소변 배양 검사 상 거대세포바이러스가 분리된 31명의 환자를 대상으로 이들의 임상 양상, 청력 손상, 발달 경과에 대하여 조사하였다.

결과: 총 연구 대상은 31 명으로 남녀비는 1.1:1이었고 평균 재태 연령은 $36.3 \pm 3.2$ 주, 평균 출생 체중은 $2,395 \pm 715 \mathrm{~g}, 37$ 주미만 미숙아는 10명(32.2\%)이었다. 자궁 내 발육 지연은 9명(29\%), 저체중 출생아는 13명(41.9\%), 극소 저체중 출생아는 2 명 $(6.5 \%)$ 이었다. 임상 소견으로는 소두증 3 명 $(9.7 \%)$ 이었고 점상 출혈, 간비종대, $\mathrm{CMV}$ 로 인한 폐렴이 각각 1명(3.2\%)이었다. 혈액 검사상 혈소판 감소증 11명(35.5\%), 백혈구 감소증 4명(12.9\%)이었다. 혈청 CMV IgM 검사는 검사를 시행한 26 명의 환아 중 15 명(57.7\%)에서 양성 소견을 보였다. 퇴원 시 시행한 청각 유발 전위 검사 결과 사망한 1 명의 환자를 제외하고 비정상인 경우는 8 명 (26.7\%)이었고 평균 36.4 개월 추적 관찰 한 결과 이 중 6 명 (75.0\%)에서 감각 신경성 청력 소실을 보였다. 12 개월 미만인 3 명과 사망한 환자를 제외하고 베일리 영유아 발달 검사와 한국형 영유아 발달 검사, 웩슬러 지능 검사를 시행한 27 명의 환자 중 6 명 $(22.2 \%)$ 은 발달 장애 소견 을 보였다. 뇌 자기 공명 영상 검사 상 뇌실확장증, 뇌실 주위 석회화, 다소뇌회증, 소뇌증, 소뇌 형성 부전의 비 정상적인 소견과 발달 장애간에는 통계학적으로 유의한 상관성을 보였고 $(P<0.05)$, 뇌실 주위 낭종, 뇌백질병변 과는 유의한 상관성을 보이지 않았다.

결론: 선천성 거대세포바이러스 감염은 자궁 내 바이러스성 태아 감염의 가장 흔한 원인으로서 선천성 감염이 의심되 는 경우 반드시 감별해야 할 질환이며 추적관찰 상 청력소실이 $20 \%$ 에서 관찰되었고 특히 뇌 자기 공명 영상에 비정상적인 소견을 보이는 경우 장기적인 신경 발달학적 추적 관찰이 요구된다. 